\title{
A Summary of the Main Biomarkers for Diagnosis and Prognosis of Sporadic Colorectal Cancer: A Review
}

\author{
Glaucia Maria de Mendonça Fernandes ${ }^{1}$, Márcia Maria Urbanin Castanhole-Nunes ${ }^{1}$, Gabriela Helena Rodrigues- \\ Fleming ${ }^{1}$, João Gomes Netinho² ${ }^{2}$ Érika Cristina Pavarino ${ }^{1}$ and Eny Maria Goloni-Bertollo ${ }^{1 *}$
}

${ }^{1}$ Department of Molecular Biology, São José do Rio Preto Medical School, Brazil

${ }^{2}$ Department of Surgery and Coloproctology, São José do Rio Preto Medical School, Brazil

Submission: December 11, 2018; Published: January 11, 2019

*Corresponding author: Eny Maria Goloni-Bertollo, PhD, Genetics and Molecular Biology Research Unit - UPGEM, Department of Molecular Biology, São José do Rio Preto Medical School, FAMERP, São José do Rio Preto, Av. Brigadeiro Faria Lima, 5416 Vila São Pedro, SP 15090-000, Brazil

\begin{abstract}
Sporadic colorectal cancer (SCRC) affects regions of the large intestine (colon) and rectum that are not of family origin. The carcinogenesis process involves the interaction between environmental and genetic factors. This tumor is characterized by intestinal obstruction, bleeding (hematochezia, enterorrhagia), an altered bowel habit, and systemic conditions, such as weight loss. Some risk factors for SCRC are age over 60 years, a diet with high saturated fat, red meat, alcohol consumption, and smoking. An early diagnosis is essential for effective patient treatment and survival. Finding more effective and less invasive tumor, such as biomarkers, are important for ensuring that people participate in cancer screenings. Some studies have evaluated molecular biomarkers, such as micro ribonucleic acids (microRNAs, or miRNAs) and genes, in relation to the pathways leading to SCRC carcinogenesis, and it has been found that many of these biomarkers are highly expressed in this type of tumor. This review shows data from the literature search in PubMed in the period from January 2017 to April 2018 focusing news biomarkers in SCRC, including microsatellite instability, genes, and micro ribonucleic acids (micro RNAs, or miRNAs), associated with diagnosis, prognosis, and treatment in blood, tissue and feces samples. Thus, this literature review shows that microsatellite instability and gene markers have been extensively studied and characterized as biomarkers in the diagnosis, prognosis, and treatment of SCRC. In addition, some miRNAs have been demonstrated as good noninvasive biomarkers in stool and plasma samples.
\end{abstract}

Keywords: Sporadic colorectal cancer; Biomarkers; Tumor; Colorectal neoplasms; Diagnosis; MicroRNAs

Abbreviations: SCRC: Sporadic Colorectal Cancer; DNA: Deoxyribonucleic Acid; CEA: Carcinoembryonic Antigen; TNM: Tumor Lymph Node Metastasis; MSI: Microsatellite Instability; CRC: Colorectal Cancer; MSS: Microsatellite Stable; SNP: Single Nucleotide Polymorphisms; VEGFC: Vascular Endothelial Growth Factor C; PDPN: Podoplanin

\section{Core Tips}

Understanding the factors that lead to SCRC carcinogenesis may contribute to understanding the disease and thus lead to improved diagnostic technologies and to the treatment of SCRC. Therefore, it is fundamental to discover the biological mechanisms, such as the influence of genes and miRNAs, that can lead to the development of SCRC. This article has as relevant evidence some of the most important biomarkers described in the years of 2017 and early 2018 to elucidate the pathways involved in the diagnosis, prognosis, screening, and treatment of SCRC.

Fernandes GMM, Castanhole-Nunes MMU, Rodrigues-Fleming GH, Pavarino EC, Goloni-Bertollo EM. A summary of the main biomarkers for diagnostic and prognostic of sporadic colorectal cancer: a review

\section{Introduction}

Sporadic colorectal cancer (SCRC) includes malignancies that affect the large intestine, which is subdivided into the colon and rectum [1], in individuals with no family history of cancer. An important feature of these tumors is that most of them originate from polyps that are elevated in the wall of the colon and/or rectum and grow very slowly, potentially taking many years to become malignant. This type of cancer is the third-most common (1.8 million) in all population in worldwide. Nearly $55 \%$ of the cases occur in more developed regions. Mortality is estimated at $9.2 \%$ of the total cases, with more deaths (52\%) occurring in the less developed regions of the world, reflecting poorer survival chances in these regions [2].

This type of cancer has a good prognosis when diagnosed early and treated primitively. Therefore, biomarkers that aid in screening for the early diagnosis of SCRC are important $[2,3]$.

The etiological factors most common for SCRC include age over 60 years [1], alcohol consumption, tobacco habits, and a diet poor in calcium and folate, as well as a diet featuring a large amount of saturated fat, red meat, bread, pasta, and refined sugar [4-7]. On the other hand, the increased intake of polyunsaturated fatty acids (chiefly derived from olive oil and seed oil), and the consumption of fruits and vegetables may provide protection against this type of cancer [6]. Other factors that may influence the development of SCRC are obesity and a sedentary lifestyle [6]. 
SCRC development involves damage to the deoxyribonucleic acid (DNA) of somatic cells by environmental factors. Thus, the development of SCRC results from the interaction of environmental factors and genetic inheritance [8].

Signs and symptoms of colorectal cancer depend on the anatomical region affected. Therefore, the understanding of physiological and clinical parameters, such as the size, extent, and dissemination of the neoplasia, is essential for appropriate treatment. This type of tumor is characterized by intestinal obstruction, bleeding (hematochezia, enterorrhagia), a change in bowel habits, and systemic settings, such as significant weight loss $[1,5]$.

The prevention of SCRC involves three main steps of action in health as follows: the primary phase's aim is to prevent the development of the disease, such as through healthy life habits [5]; the secondary phase is prevention through an early diagnosis by a physical examination performed by a proctologist, laboratory tests, fecal occult blood test, carcinoembryonic antigen (CEA) test, and imaging screenings (colonoscopy, proctosigmoidoscopy); and the tertiary phase is the prevention of SCRC with the relief of the symptoms and the prevention of consequences [8].

The miRNAs are small, non-coding RNAs with approximately 22 nucleotides capable of regulating gene expression through the degradation or repression of translation of target mRNA molecules. They can influence some cellular functions, such as proliferation, differentiation, apoptosis, stress response, among others. There are studies relating them to tumor activity, where oncogenic miRNAs reveal increased expression in malignant neoplasms. Cancer is influenced by epigenetic factors that require the inactivation of tumor suppressor genes and activation of proto-oncogenes. This whole process occurs post-transcriptionaly because the miRNA gene is transcribed by RNA polimerase II to generate a primary microRNA (pri-miRNA). The pri-miRNA were processed in the nucleus by Drosha complex and double-stranded RNA ligation protein (pre-miR). The pre-miR is transported to cytoplasm by means of Exportin-5, and then processed by Dicer enzyme with a removed stem-loop, the RNA-duplex. This RNAduplex is incorporated to RISC complex and the double-stranded separated. The complementar strand is degraded and the other remains with the RISC complex, forming the mature miRNA [9-11].

This review shows data from the literature search in PubMed in the period from January 2017 to April 2018 focusing news biomarkers in SCRC, including microsatellite instability, genes, and micro ribonucleic acids (micro RNAs, or miRNAs), associated with diagnosis, prognosis, and treatment in blood, tissue and feces samples.

\section{Diagnosis}

If previous exams do not lead to a diagnosis but there are still signs and symptoms or a positive result for stool occult blood, the patient should be referred for a colonoscopy. This exam investigates the entire length of the intestine, allowing for the identification of polyps or more serious lesions. A polypectomy enables the removal of polyps for performing a biopsy to confirm the diagnosis and to prevent the evolution of this problem into a serious lesion [12].

SCRC staging can be performed by TNM ( $\mathrm{T}=$ Tumor, $\mathrm{N}=$ Lymph Node, $\mathrm{M}=$ Metastasis), considered the best prognostic indicator. It is possible to identify the level of penetration of the intestinal wall, the number of committed lymph nodes, and the presence or absence of remote metastases [13,14].

The SCRC is a polycystic and multifactorial disease that can arise due to epigenetic and genetic changes in the oncogenes, tumor suppressor genes, mismatch repair genes, regulatory genes in cell cycle, as well as the influences of environmental factors [15]. Currently, the most studied biomarkers in SCRC involve the instability of microsatellites, gene markers, and miRNAs.

\section{Microsatellite Instability (MSI)}

One of the main molecular pathways where the genetic alterations that result in carcinogenesis occur is microsatellite instability (MSI) [15]. Microsatellites are non-coding segments of DNA that contain repetitions of 1-6 nucleotides and are prone to errors during DNA synthesis. The DNA regions microsatellites are most prone to failure due to the incompatibility mismatch repair mechanism (MMR) [16]. The main microsatellites used in the panel to investigate the colorectal cancer (CRC) are BAT25, BAT26, D2S123, D5S346, and D17S250, which are localized in the genes of c-Kit (cr.4q12), hMSH2 (cr. 2p), hMSH2 (cr. 2p), APC (cr. 5q21q22), and BRCA1 (cr.17q11.2-q12) respectively [3].

According to the Bethesda panel, the MSI can be divided into three groups: microsatellites instability-high, (MSI-H), defined as having $30 \%$ of unstable loci using mononucleotide or dinucleotide markers [15-17]; instability-low microsatellites (MSI-L), which contain $10-30 \%$ of unstable loci; and microsatellite stable (MSS) with less than $10 \%$ of unstable loci [17].

Some papers present the MSI as a marker of a significant prognostic factor in the early SCRC stages $[3,15,18]$. Zhang \& collaborators [19] showed that the MS-I status was found to be significantly correlated with good or moderate histopathological differentiation associated with low carcinoembryonic antigens and CA-19-9 antigen values. They carried out the analysis using microsatellite markers, including two mononucleotides (BAT25, BAT26) and three dinucleotides (D2S123, D5S346, D17S250). In addition, the authors researched the association between MSI status and single nucleotide polymorphisms (SNP) in genes' relationship with DNA repair as ERCC1 c.C354T and XRCC1 c. G1196A, and no significant association was found in this analysis. However, after treatment with mFOLFOX6 adjuvant chemotherapies (including the drugs of leucovorin calcium, fluorouracil, and oxaliplatin), the authors observed an association between the presence of MSI status and ERCC1 and XRCC1 SNPs. Therefore, these MSI status-associated polymorphisms may contribute to the treatment of patients with SCRC [19].

Losso et al. [3] evaluated microsatellite markers and found that $42 \%$ of patients with SCRC had MSI status, including the allelic loss 
of microsatellite markers as BAT25, BAT26, D2S123, D5S346, and D17S2720; the amplification of BAT26 (100\%); and the reduction of D17S2720 (85.4\%), confirming its use as a prognostic marker in colorectal carcinogenesis. Other studies investigating MSI status showed a high association among microsatellite loci, BAT25 and BAT26, and the more aggressive histopathological types (tubulovillous/villous adenoma) of SCRC [18].

\section{Molecular Biomarkers}

Mutations in phosphatidylinositol-4,5-bisphosphate 3-kinase catalytic subunit alpha (PIK3CA) catalytic subunit of phosphatidylinositol 3-kinase (PI3K), Human Epidermal growth factor Receptor-type 2 (HER2), RAS (Rat sarcoma viral oncogene homolog family), and Serine/threonine-protein kinase B-raf (BRAF) are considered to be emerging biomarkers for SCRC. Theses markers were associated with cell growth, proliferation, and survival, including the KRAS/BRAF/MAPK and PI3K/AKT pathways. Thus, the mutations of genes that participate in these pathways are associated with a worse prognosis for SCRC, mainly leading to metastasis, tumor recurrence, and resistance to treatment involving many drugs, such as Cetuximab, an anti-EGFR (Epidermal growth factor receptor) monoclonal antibody treatment [20].

Mutations in Kirsten rat sarcoma viral oncogene homolog (KRAS) codons 12,13, and other codons can be a predictor of a poor prognosis and resistance to EGFR inhibition [21-24]. Mutations in BRAF (BRAFnon-V600E) may be able to contribute to a lesser benefit of anti-EGFR treatment. In addition, these mutations can be a predictor of a response to BRAFnon-V600E inhibitors, which are still under investigation as vemurafenib [20,25]. PIK3CA and HER2 mutations are also predictors of resistance to EGFR inhibitors and a response to prophylactic aspirin use and HER2 inhibitors, respectively [20].

Other genes alterations less studied but very important associated with the activation in tumor development and progression of SCRC are polymorphisms of MAPK-interacting kinase 1 (MKNK1) and P53 tumor suppressor (TP53) genes [26,27]. High expression in the tyrosine-protein kinase transmembrane receptor (ROR1) gene, a member of the ROR receptor tyrosine kinase family and a transmembrane glycoprotein, which is also an important biomarker, has been associated with a longer overhaul survival [28].

Genes related to angiogenesis, lymphatic invasion, and distance metastasis also may represent possible biomarkers for poor prognosis in SCRC. A study analyzed the participation of a lymphangiogenic gene set with a six-gene signature in the invasion potential, including two main drivers of lymphangiogenesis, vascular endothelial growth factor C (VEGFC) and neuropilin- 2 (Nrp-2), and other minor drivers, such as lymphatic vessel endothelial hyaluronan receptor 1 (LYVE-1), mannose receptor-C type 1 (MRC1), chemokine (C-C motif) ligand 21 (CCL-21), and podoplanin (PDPN). In the metastatic setting, the high expression of VEGFC and NRP-2 in primary aggressive mesenchymal colorectal tumors was evidenced, using bioinformatics analysis in primary and hepatic metastatic SCRC [29]. Table 1 \& Figure 1 [30,31] showed the main gene biomarkers and pathway in SCRC. Ras proteins function as both on and off (guanosine diphosphate (GDP)/guanosine triphosphate (GTP) - binary switches), where the GDP/GTP cycle is regulated by guanine nucleotide exchange factors (RasGEFs) that promote the formation of the form that activates RAS-GTP, and GTPase activation proteins (GAPs) stimulate GTP hydrolysis and the formation of the inactive RAS-GDP form. In normal quiescent cells, it appears in the inactive RAS-GDP form until it receives extracellular stimuli that cause the transient formation of the active form when bound to RAS-GTP. Both wild-type and mutant, when activated, RAS-GTP binds to a spectrum of effector pathways to the nucleus. Ras mutant proteins do not undergo action on GAP proteins by making RAS-GTP proteins continuously active, which leads to stimulus independence and the persistent activation of nucleic effectors, including RAF $\rightarrow$ mitogen-activated protein kinase (MEK) $\rightarrow$ ERK and phosphatidylinositol 3-kinase (PI3K) $\rightarrow$ $\mathrm{AKT} \rightarrow$ mammalian rapamycin target (mTOR), to promote cell proliferation, survival, angiogenesis, apoptosis inhibition and metastasis. Vascular endothelial growth factor (VEGF) is the major gene involved in metastasis for promoting vessel formation (Adapted from Roberts \& Stinchombe [31]). The summary of the main miRNAs involved in the regulation of the genes of this pathway is represented [32].

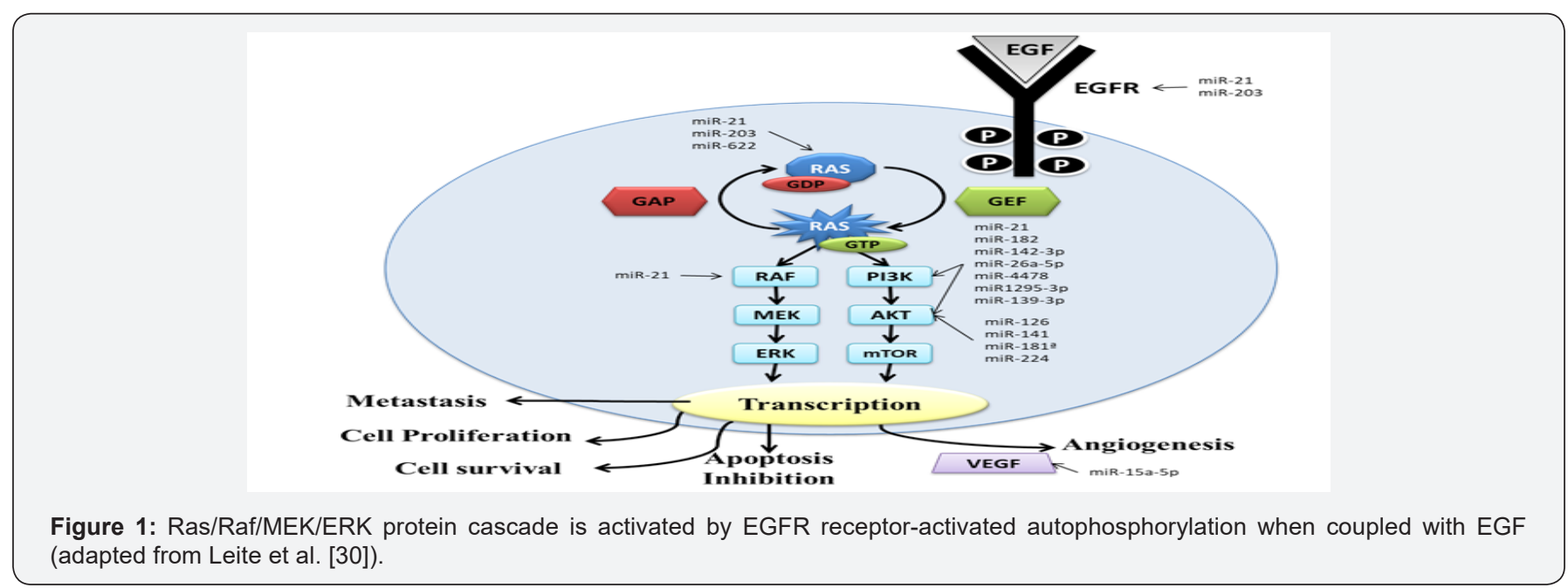




\section{Advanced Research in Gastroenterology \& Hepatology}

Table 1: The main gene biomarkers.

\begin{tabular}{|c|c|c|c|c|}
\hline Gene & \multicolumn{2}{|l|}{ Biomarker Characteristics } & Pathway & Authors \\
\hline HER2 and KRAS & $\begin{array}{l}\text { KRAS exons 2, } 3 \text { and 4; } \\
\text { NRAS exons 2, } 3 \text { and } 4 \text {; } \\
\text { HER2 overexpression }\end{array}$ & predictive & $\begin{array}{l}\text { EGFR signalling pathway / cell } \\
\text { proliferation and survival }\end{array}$ & [17] \\
\hline KRAS & p.G12C and p.G12V mutations in codon 12 & $\begin{array}{l}\text { poor prognostic } \\
\text { and treatment }\end{array}$ & $\begin{array}{l}\text { PI3K/AKT/MTOR and RAF/ } \\
\text { MEK/ERK cellular prolifera- } \\
\text { tion pathways }\end{array}$ & [18] \\
\hline $\begin{array}{l}\text { KRAS, NRAS, BRAF and } \\
\text { PIK3CA }\end{array}$ & $\begin{array}{c}\text { KRAS p.G12D, p.G13D, p.G12S, p.G12V, p.D47Y, p.Q61L; } \\
\text { NRAS p.G12D; } \\
\text { PIK3CA p.H1047Y } \\
\text { TP53 p.G244C, p.R110C, p.R248W, p.R175H, p.R282W, } \\
\text { p.R273C, p.R306* }\end{array}$ & $\begin{array}{l}\text { poor prognostic } \\
\text { and treatment }\end{array}$ & $\begin{array}{l}\text { RAS/BRAF/PIK3CA; cell prolif- } \\
\text { eration and survival }\end{array}$ & [19] \\
\hline $\begin{array}{l}\text { KRAS, NRAS, BRAF and } \\
\text { PIK3CA }\end{array}$ & $\begin{array}{l}\text { PIK3CA exons } 9 \text { and 20; } \\
\text { BRAF V600E mutation }\end{array}$ & predictive & $\begin{array}{c}\text { EGFR signalling and in partic- } \\
\text { ular the PI3K pathway / cell } \\
\text { proliferation and survival }\end{array}$ & [20] \\
\hline KRAS & KRAS mutation & $\begin{array}{l}\text { poor prognostic } \\
\text { and treatment }\end{array}$ & $\begin{array}{l}\text { MEK/ERK and/or PI3K/AKT } \\
\text { signalling pathways }\end{array}$ & [21] \\
\hline BRAF & BRAF V600E mutation & predictive & RAS/BRAF & [22] \\
\hline TP53 & $\begin{array}{c}\text { Rare haplotype cccgaRDa in rs1614984, rs77697176, } \\
\text { rs12947788, rs1800372, rs2909430, rs1042522, } \\
\text { rs17878362 and rs11652704 }\end{array}$ & predictive & Apoptosis inhibition & [24] \\
\hline ROR1 & High gene expression & poor prognostic & $\begin{array}{l}\text { Cell differentiation, prolifera- } \\
\text { tion and survival. }\end{array}$ & [25] \\
\hline VEGFC, Nrp-2 & High gene expression & $\begin{array}{l}\text { poor prognostic } \\
\text { and treatment }\end{array}$ & $\begin{array}{l}\text { Lymphatic invasion and angio- } \\
\text { genesis. }\end{array}$ & [26] \\
\hline
\end{tabular}

\section{MiRNAs}

The miRNAs have been extensively studied to aid in the early diagnosis of SCRC, mainly in stool and plasma samples. Blood and feces samples are the best types of specimens to perform the diagnosis, since they are less invasive, and patients accept this type of examination better. Therefore, studies with these types of samples are so important. Some studies observed that in feces samples, it is possible to increase the specificity and sensibility for diagnosing SCRC compared with blood tests [33,34].

In a recent study, 20 miRNAs showed inhibition and 12 induction in the carcinogenesis CRC process. MiR-34a, miR-135, miR29, miR-126, miR-320, miR-200 family, miR-9, miR-497, miR-152, miR-187, miR-519, miR-155, miR-497, miR-375, miR-140-5p, miR-144, miR-638, miR-99b-5p, miR-101, and miR-409-3p were associated with the inhibition p53 acetylation process and the WNT signaling pathway; reduction methylation; the inhibition of cell proliferation, migration, and invasion; the inhibition of tumor growth and metastasis; and the induction of sensitivity to chemotherapeutic drugs, the inactivation of the transforming growth factor beta - TGF-B pathway, and the epithelial to Mesenchymal transition [35]. However, miR-21, miR-345, miR-148b, let-7c, let7a, miR-499-5p, miR-92, miR-503, miR-222, miR-181b, miR-1246, and miR-20a were associated with the induction of cell proliferation (DNA methyltransferase and KRAS gene), invasion and metastasis promotion (programmed cell death 4, forkhead box 04), the induction of cell proliferation and invasion (BCL-2-associated athanogene, Cholecystokinin B receptor, Serine/threonine kinase 24, Cyclin G2), and others [35].
A recent bioinformatics study involving the 368 target genes in the differential stages (late cancer-surrounding tissues, cancersurrounding tissues, and primary cancer tissues) of SCRC showed that miRNAs can be used as tools for controlling the occurrence and development of tumor cells. When the researchers compared the primary cancer-surrounding tissues with the late cancersurrounding tissues, no upregulation or downregulation of miRNAs was identified. However, in the analysis of cancer tissues compared with cancer-surrounding tissues, 275 upregulated and 89 downregulated miRNAs were observed. They also compared the primary cancer tissues with the late cancer tissues and detected four downregulated and no upregulated miRNAs. Amongst the upregulated miRNAs, the highest expressions were to hsa-miR-3613-3p, HBII-85-26, hsa-miR-4668-5p, hsa-miR-663b, and hsa-miR-31-5p. Meanwhile the top downregulated miRNAs were hsa-miR-378a-3p, hsa-mir-6722, and hsa-miR-342-3p. All of the miRNAs identified by the study were associated with the proteoglycan process, Want signaling pathway, choline metabolism, thyroid hormone signaling pathway, and other pathways involved in cell proliferation, metastasis, and angiogenesis [36].

A study in vitro explored the involvement of miRNAs in SCRC; for example, the miR-15a-5p is an important miRNA involved in the pathway of cell proliferation and survival. This miRNA when upregulated alters the expression of the proto-oncogene MYB, a transcription factor that is essential for proliferation and cell survival. This study demonstrated that miR-15a-5p was associated with SCRC and low patient survival, but it was not associated with metastasis. The authors further suggested that miR-15a-5p may 


\section{Advanced Research in Gastroenterology \& Hepatology}

be considered a potential biomarker for SCRC when evaluated in a plasma sample [37].

Some studies evaluated the expression of miR-21 in relation to genes leading to SCRC carcinogenesis found that this high expression of miRNA is strongly associated with SCRC [38-41]. A meta-analysis including 25 diagnostic studies and 32 prognostic studies of SCCR showed that miR-21 is an important diagnostic biomarker in plasma samples and is an important prognostic biomarker in tissue samples. These miRNAs were upregulated and were indicated for diagnostic use with $64 \%$ sensitivity and $85 \%$ specificity [39].

More specifically, one study with 105 paired tumor and tumoradjacent normal tissue specimens showed the overexpression of miR-21 with an oncogenic role by reducing the protein expression of phosphatase and tensin homolog (PTEN), subsequently elevating phosphorylated Akt ( $\mathrm{p}-\mathrm{AKT})$. These proteins are responsible for inhibiting apoptosis and promoting cellular proliferation, invasion, and cell cycle progression. In this study, it was also observed that patients with an advanced tumor-nodemetastasis (TNM) stage, lymph node metastasis, local invasion, and higher serum CEA levels presented the overexpression of miR-21 [40].

Others studies have been performed in peripheral blood and fecal content, targeting early diagnosis and less invasive methods. For example, the study of Tsukamoto and collaborators that studied tissues and peripheral blood showed that exosomal miR21 may be a promising noninvasive biomarker for diagnosis and a predictor of recurrence and prognosis in CRC patients [41].

A new research study about the circulating miRNA acting as a diagnostic biomarker for early colorectal cancer was realized by a bioinformatics analysis in two databases - the Data from Gene Expression Omnibus database and The Cancer Genome Atlaswhich identified miR-182 and miR-20a significantly upregulated in CRC tissues. These circulating miRNAs were used for validation as novel potential plasma diagnostic biomarkers in SCRC. In the plasma samples of 50 CRC patients, 50 adenoma patients, and 50 healthy controls were validated as potential diagnostic. The miR182 and miR-20a showed high expression in the CRC patients in comparison with the adenoma patients and healthy controls [42]. This study suggested that the circulating miR-182 in plasma could be a potential biomarker with $91 \%$ specificity and $78 \%$ sensitivity for the early diagnosis of CRC patients. This is important because the miR-182 has been reported as a miRNA that could inhibit the epithelialto-mesenchymal transition, inhibit metastasis, and promote chemoresistance through the PI3K/AKT pathway [42].

Nine other miRNAs that are important upon cell functions, including cell apoptosis, cell cycle, and death, that may refer to SCRC progression such as miR-92a, miR-141, miR-181a, miR-200b, miR-224, and miR-429, showed high expression, whereas the miR-125b, miR-143, and miR-145 showed down expression, and the four already-cited miRNAs in this review (miR-21, miR-106a, miR-203 were of higher expressions, and miR-126 was of a lower expression). A meta-analysis searched in literature until May 2017 that evaluated 63 relevant articles showed 13 different miRNAs in blood and tissue samples associated with SCRC progression. In the tissue samples, the miR-21, miR-181a, miR-224, and miR-126 had a significant prognostic value, whereas only miR-141 was found in sample blood [43].

A research study realized in Brazil showed a higher expression of miR-21 and miRNA-203 in tumors compared with adjacent non-tumor samples. MiRNA-203 was also associated with patients in advanced stages and patients in clinical remission of SCRC [38].

The analysis of stools and plasma samples found that expression levels of miR-4478 and miR-1295b-3p were significantly decreased in stools samples in SCRC patients, and there was no difference in expression between miRNAs studied in the plasma samples [44]. In another study with circulating blood samples miR-139-3p and miR-622, was founded down expression and overexpression, respectively. The miRNAs miR622 (colorectal) and miR-139 (glioma) are related to proliferation, survival, migration, and invasion, involved in RAS/PI3K/AKT pathway $[45,46]$.

Another study on fecal samples of patients with CRC or adenomas and healthy individuals showed higher expressions of miR-21 and miR-106a in individuals with SCRC compared with the control group. In conclusion they found that these miRNAs can be effectively potential biomarkers in a fresh stool sample as a promising and non-invasive marker diagnosis of early colorectal neoplasia [46]. The main miRNAs biomarkers are present in Table 2 \& Figure $1[30,31]$.

Table 2: The main miRNAs biomarkers.

\begin{tabular}{|c|c|c|c|c|c|}
\hline MiRNAs & miRNAs Expression & $\begin{array}{c}\text { Biomarker Cha- } \\
\text { racteristics }\end{array}$ & Pathway and/or Function & Gene Regulation & Authors \\
\hline $\begin{array}{c}368 \text { miRNAs with differential } \\
\text { expression }\end{array}$ & $\begin{array}{c}275 \text { up } \\
93 \text { down }\end{array}$ & $\begin{array}{c}\text { Predictive and } \\
\text { poor prognostic }\end{array}$ & Cell proliferation and survival & $-*$ & {$[32]$} \\
\hline miR-15a-5p & Up & $\begin{array}{c}\text { Predictive and } \\
\text { poor prognostic }\end{array}$ & cell proliferation and survival & High / MYB & {$[33]$} \\
\hline $\begin{array}{c}\text { miR-21, } \\
\text { miR-203 }\end{array}$ & $\begin{array}{c}\text { Up } \\
\text { Down }\end{array}$ & $\begin{array}{c}\text { Predictive and } \\
\text { poor prognostic }\end{array}$ & $\begin{array}{c}\text { EGFR and KRAS, RAS/BRAF/PIK- } \\
\text { 3CA pathway; cell proliferation and } \\
\text { survival }\end{array}$ & $\begin{array}{c}\text { High / EGFR and } \\
\text { KRAS }\end{array}$ & $\begin{array}{c}{[34]} \\
\text { miR-21 }\end{array}$ \\
\hline Up & $\begin{array}{c}\text { Predictive and } \\
\text { poor prognostic }\end{array}$ & Cell proliferation and survival & $-*$ & {$[35][37]$} \\
\hline
\end{tabular}




\section{Advanced Research in Gastroenterology \& Hepatology}

\begin{tabular}{|c|c|c|c|c|c|}
\hline miR-21 & Up & $\begin{array}{l}\text { Predictive and } \\
\text { poor prognostic }\end{array}$ & $\begin{array}{l}\text { PI3K/AKT pathway, cell prolifera- } \\
\text { tion and survival }\end{array}$ & $\begin{array}{l}\text { High / PTEN and } \\
\text { p-AKT }\end{array}$ & {$[36]$} \\
\hline miR-182 & Up & $\begin{array}{l}\text { Predictive and } \\
\text { poor prognostic }\end{array}$ & $\begin{array}{l}\text { inhibit the epithelial to-mesenchy- } \\
\text { mal transition (EMT), the metasta- } \\
\text { sis and PI3K/AKT pathway }\end{array}$ & $-*$ & {$[38]$} \\
\hline $\begin{array}{c}\text { miR-21 } \\
\text { miR-126 } \\
\text { miR-141 } \\
\text { miR-181a } \\
\text { miR-224 }\end{array}$ & $\begin{array}{c}\text { Up } \\
\text { Down } \\
\text { Up } \\
\text { Up } \\
\text { Up }\end{array}$ & Poor prognostic & $\begin{array}{l}\text { Cell apoptosis, cell cycle, cell death, } \\
\text { cell invasion, cell migration, cell } \\
\text { proliferation, AKT1/FOXO3 signal- } \\
\text { ing, RHOA signaling. }\end{array}$ & $-*$ & [39]. \\
\hline $\begin{array}{l}\text { miR-142-3p, miR-26a-5p, } \\
\text { miR-4478 and miR1295-3p }\end{array}$ & Down & Diagnostic & Regulator of cell growth & $-*$ & {$[40]$} \\
\hline $\begin{array}{l}\text { miR-139 } \\
\text { miR-622 }\end{array}$ & $\begin{array}{l}\text { Down } \\
\text { UP }\end{array}$ & Diagnostic & $\begin{array}{l}\text { Cell progression, proliferation and } \\
\text { metastasis [42] }\end{array}$ & $-*$ & {$[41]$} \\
\hline
\end{tabular}

* The authors did not perform the functional analysis (the influence of miRNA on the regulation of genes), however in Figure 1 is possible verify the influence of these miRNAs in the pathways.

\section{Conclusion}

This literature review showed some biomarkers associated with the diagnosis, prognosis, and treatment of SCRC. Microsatellite instability and genes biomarkers have been extensively studied and characterized as markers of diagnosis and poor prognosis in SCRC. We highlighted that some miRNAs are good noninvasive diagnostic markers present in stool and plasma samples. The majority of miRNAs are involved in cell proliferation, metastasis, and angiogenesis.

\section{Acknowledgment}

Supported by São Paulo Research Foundation (FAPESP), No. 2011/23969-1 and No. 2012/02473-0; Coordination for the Improvement of Higher Education Personnel (CAPES) (Master grant) and National Council of Technological and Scientific Development (CNPq), No. 310582/2014-8.

\section{References}

1. (2018) Instituto Nacional do Câncer (INCA). Ministério da Saúde.

2. Bray F, Ferlay J, Soerjomataram I, Siegel RL, Torre LA, et al. (2018) Global cancer statistics 2018: GLOBOCAN estimates of incidence and mortality worldwide for 36 cancers in 185 countries. CA Cancer J Clin 68(6): 394-424.

3. Losso GM, Moraes RDS, Gentili, AC, Messias-Reason IT (2012) Microsatellite instability-MSI markers (BAT26, BAT25, D2S123, D5S346, D17S250) in rectal cancer. Arq Bras Cir Dig 25(4): 240-244.

4. Maisonneuve $\mathrm{P}$ (2008) Smoking and colorectal cancer: a meta-analysis. JAMA 300(23): 2765-2778.

5. Pelucchi C, Tramacere I, Boffetta P, Negri E, La Vecchia C (2011) Alcohol consumption and cancer risk. Nutr Cancer 63(7): 983-990.

6. Hermann S, Rohrmann S, Linseisen J (2009) Lifestyle factors, obesity and the risk of colorectal adenomas in EPIC-Heidelberg. Cancer Causes Control 20: 1397-1408.

7. Johnson CM, Wei C, Ensor JE, Smolenski DJ, Amos CI, et al. (2013) Meta-analyses of colorectal cancer risk factors. Cancer Causes Control 24(Suppl 6): 1207-1222.

8. Ahrendt SA, Chown JT, Yang SC, Wu L, Zhang MJ, et al. (2000) Alcohol consumption and cigarette smoking increase the frequency of p53 mutations in non-small cell lung cancer. Cancer Res 60(12): 31553159.

9. Amaral BA, Weege Nonaka CF, Freitas RA, Souza LB, Pinto LP (2010)
MicroRNAs - Biogênese, funções e seu papel potencial na carcinogênese oral. Odontol Clí Cient 9(2): 105-109.

10. MacFarlane La, Murphy PR (2010) MicroRNA: Biogenesis, Function and Role in Cancer. Curr Genomics 11(7): 537-561.

11. Bartel DP (2004) MicroRNAs: Genomics, biogenesis, mechanism, and function. Cell 116(2): 281-297.

12. Winawer S, Fletcher R, Rex D, Bond J, Burt R, et al. (2003) Colorectal cancer screening and surveillance: clinical guidelines and rationaleupdate based on new evidence. Gastroenterol 124(2): 544-560.

13. Andrade SMS, Pereira FL (2007) Câncer colorretal sincrônico-relato de caso e revisão de literatura. Rev Bras Coloproct 1(27): 69-79.

14. (2018) American Cancer Society.

15. Mahasneh A, Al-Shaheri F, Jamal E (2017) Molecular biomarkers for an early diagnosis, effective treatment and prognosis of colorectal cancer: Current updates. Exp Mol Pathol 102(3): 475-483.

16. Das V, Kalita J, Pal M (2017) Predictive and prognostic biomarkers in colorectal cancer: A systematic review of recent advances and challenges. Biomed Pharmacother 87: 8-19.

17. Laghi L, Bianchi P, Malesci A (2008) Differences and evolution of the methods for the assessment of microsatellite instability. Oncogene 27(49): 6313-6321.

18. Takiyama A, Tanaka T, Yamamoto Y, Hata K, Ishihara S, et al. (2017) Microsatellite Status of Primary Colorectal Cancer Predicts the Incidence of Postoperative Colorectal Neoplasms. Anticancer Res 37(10): 5785-5790.

19. Zhang L, Zhao J, Yu B, Song X, Sun G, et al. (2017) Correlations between microsatellite instability, ERCC1/XRCC1 polymorphism and clinical characteristics, and FOLFOX adjuvant chemotherapy effect of colorectal cancer patients. Cancer Genet 218-219: 51-57.

20. Vakiani E (2017) Molecular Testing of Colorectal Cancer in the Modern Era: What Are We Doing and Why? Surg Pathol Clin 10 (4): 1009-1020.

21. Jones RP, Sutton PA, Evans JP, Clifford R, McAvoy A, et al. (2017) Specific mutations in KRAS codon 12 are associated with worse overall survival in patients with advanced and recurrent colorectal cancer. Br J Cancer 116(7): 923-929.

22. Li W, Qiu T, Guo L, Ying J (2017) Major challenges related to tumor biological characteristics in accurate mutation detection of colorectal cancer by next-generation sequencing. Cancer Lett 410: 92-99.

23. Lièvre A, Ouine B, Canet J, Cartier A, Amar Y, et al. (2017) Protein biomarkers predictive for response to anti-EGFR treatment in RAS wild-type metastatic colorectal carcinoma. Br J Cancer 117(12): 18191827. 
24. Williams SP, Barthorpe AS, Lightfoot H, Garnett MJ, McDermott U (2017) High-throughput RNAi screen for essential genes and drug synergistic combinations in colorectal cancer. Sci Data 4: 170139.

25. Shinozaki E, Yoshino T, Yamazaki K, Muro K, Yamaguchi K, et al. (2017) Clinical significance of BRAF non-V600E mutations on the therapeutic effects of anti-EGFR monoclonal antibody treatment in patients with pretreated metastatic colorectal cancer: the Biomarker Research for anti-EGFR monoclonal Antibodies by Comprehensive Cancer genomics (BREAC) study. Br J Cancer 117(10): 1450-1458.

26. Berger MD, Stintzing S, Heinemann V, Yang D, Cao S, Sunakawa Y, et al. (2017) Impact of genetic variations in the MAPK signaling pathway on outcome in metastatic colorectal cancer patients treated with firstline FOLFIRI and bevacizumab: Data from FIRE-3 and TRIBE trials. Ann Oncol 28 (11): 2780-2785.

27. Škereňová M, Halašová E, Matáková T, Jesenská L, Jurečeková J, et al. (2017) Low Variability and Stable Frequency of Common Haplotypes of the TP53 Gene Region in Colorectal Cancer Patients in a Slovak Population. Anticancer Res 37(4): 1901-1907.

28. Zhou JK, Zheng YZ, Liu XS, Gou Q, Ma R, et al. (2017) ROR1 expression as a biomarker for predicting prognosis in patients with colorectal cancer. Oncotarget 8(20): 32864-32872.

29. Vellinga TT, Kranenburg O, Frenkel N, Ubink I, Marvin D, et al. (2017) Lymphangiogenic Gene Expression Is Associated with Lymph Node Recurrence and Poor Prognosis After Partial Hepatectomy for Colorectal Liver Metastasis. Ann Surg 266(5): 765-771.

30. Leite CAVG, Costa JVG, Callado RB, Torres JNL, Lima-Junior RCP, et al. (2012) Receptores tirosina quinase: implicações terapêuticas no câncer. Rev Bras Oncol Clín 8: 130-142.

31. Roberts PJ, Stinchcombe TE (2013) KRAS mutation: should we test for it, and does it matter? J Clin Oncol 31(8): 1112-1121.

32. Ahmed FE, Jeffries CD, Vos PW, Flake G, Nuovo GJ, et al. (2009) Diagnostic microRNA markers for screening sporadic human colon cancer and active ulcerative colitis in stool and tissue. Cancer Genomics Proteomics 6(5): 281-295.

33. Schee K, Fodstad Ø, Flatmark K. (2010) MicroRNAs as biomarkers in colorectal cancer. Am J Pathol 177(4): 1592-1599.

34. Mármol I, Sánchez-de-Diego C, Pradilla Dieste A, Cerrada E, Rodriguez Yoldi MJ (2017) Colorectal Carcinoma: A General Overview and Future Perspectives in Colorectal Cancer. Int J Mol Sci 18(1): 197.

35. Du B, Wu D, Yang X, Wang T, Shi X, et al. (2018) The expression and significance of microRNA in different stages of colorectal cancer. Medicine (Baltimore) 97(5): 9635.

36. Kontos CK, Tsiakanikas P, Avgeris M, Papadopoulos IN, Scorilas A (2017) miR-15a-5p, A Novel Prognostic Biomarker, Predicting Recurrent Colorectal Adenocarcinoma. Mol Diagn Ther 21(4): 453-464.

37. Carvalho TI, Novais PC, Lizarte FS Neto, Sicchieri RD, Rosa MS, et al. (2017) Analysis of gene expression EGFR and KRAS, microRNA-21 and microRNA-203 in patients with colon and rectal cancer and correlation with clinical outcome and prognostic factors. Acta Cir Bras 32(3): 243 250 .

38. Peng Q Zhang X, Min M, Zou L, Shen P, et al. (2017) The clinical role of microRNA-21 as a promising biomarker in the diagnosis and prognosis of colorectal cancer: a systematic review and meta-analysis. Oncotarget 8(27): 44893-44909.

39. Wu Y, Song Y, Xiong Y, Wang X, Xu K, et al. (2017) MicroRNA-21 (Mir-21) Promotes Cell Growth and Invasion by Repressing Tumor Suppressor PTEN in Colorectal Cancer. Cell Physiol Biochem 43(3): 945-958.

40. Tsukamoto M, Iinuma H, Yagi T, Matsuda K, Hashiguchi Y (2017) Circulating Exosomal MicroRNA-21 as a Biomarker in Each Tumor Stage of Colorectal Cancer Oncol 92: 360-370.

41. Liu X, Xu T, Hu X, Chen X, Zeng K, et al. (2018) Elevated circulating miR182 acts as a diagnostic biomarker for early colorectal cancer. Cancer Manag Res 10: 857-865.

42. Gao S, Zhao ZY, Wu R, Zhang Y, Zhang ZY (2018) Prognostic value of microRNAs in colorectal cancer: a meta-analysis. Cancer Manag Res 10: 907-929.

43. Ghanbari R, Rezasoltani S, Hashemi J, Mohamadkhani A, Tahmasebifar A, et al. (2017) Expression analysis of previously verified fecal and plasma dow-regulated microRNAs (miR-4478, 1295-3p, 142-3p and 26a-5p), in FFPE tissue samples of CRC patients. Arch Iran Med 20(2): 92-95.

44. Ng L, Wan TM-H, Man JH-W, Chow AK, Iyer D, et al. (2017) Identification of serum miR-139-3p as a non-invasive biomarker for colorectal cancer. Oncotarget 8(16): 27393-27400.

45. Wang H, Yan X, Ji LY, Ji XT, Wang P, et al. (2017) miR-139 Functions as An Antioncomir to Repress Glioma Progression Through Targeting IGF-1 R, AMY-1, and PGC-1 $\beta$. Technol Cancer Res Treat 16(4): 497-511.

46. Yang X, Zhong J, Ji Y, Li J, Jian Y, et al. (2015) The expression and clinical significance of microRNAs in colorectal cancer detecting. Tumor Biol 36(4): 2675-2684.

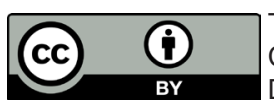

\section{Your next submission with JuniperPublishers will reach you the below assets}

- Quality Editorial service

- Swift Peer Review

- Reprints availability

- E-prints Service

- Manuscript Podcast for convenient understanding

- Global attainment for your research

- Manuscript accessibility in different formats

( Pdf, E-pub, Full Text, audio)

- Unceasing customer service

Track the below URL for one-step submission https://juniperpublishers.com/online-submission.php 